\title{
Epilepsirelaterte psykoser
}

BAKGRUNN Epilepsirelaterte psykoser ligger i grenselandet mellom nevrologi og psykiatri. Hensikten med denne artikkelen er å gi en kort oversikt over hva vi i dag vet om slike psykoser samt å gi noen råd om behandlingen.

KUNNSKAPSGRUNNLAG Denne oversikten er basert på et skjønnsmessig utvalg av artikler funnet etter søk i PubMed samt forfatternes egen erfaring med pasientgruppen.

RESULTATER Psykoser ved epilepsi kan opptre under, etter og mellom anfall. I tillegg kan psykoser opptre som bivirkning av antiepileptika og som såkalt alternativ psykose. Den sistnevnte psykoseformen kan oppstå hos pasienter som ved hjelp av behandling (medikamenter eller kirurgil er blitt helt anfallsfri. Iktale psykoser og majoriteten av postiktale psykoser er ofte av så kort varighet at behandling med antipsykotika er uaktuelt. Å optimalisere den antiepileptiske behandlingen blir i slike tilfeller det viktigste tiltaket. Ved interiktale psykoser og hos noen pasienter med særlig langvarige eller stadig tilbakevendende postiktale psykoser kan behandling med antipsykotika være indisert.

FORTOLKNING De ulike epilepsirelaterte psykoseformene behandles forskjellig, og noen behandles med antipsykotika. Vi anbefaler da å velge medikamenter som i liten grad senker anfallsterskelen, for eksempel risperidon.

Allerede i en babylonsk tekst fra år 1050 f.Kr. er det beskrevet en person med epilepsi som utviklet psykose (1).

Sammenliknet med den generelle befolkning er det $\mathrm{i}$ en rekke studier funnet økt forekomst av psykiatriske lidelser blant personer med epilepsi $(2,3)$. Omvendt er det også funnet økt forekomst av epilepsi blant personer med psykiatriske sykdommer $(4,5)$. Mens det i faglitteraturen har vært stor oppmerksomhet rundt den bidireksjonale sammenhengen mellom epilepsi og depresjon, har sammenhengen mellom epilepsi og psykose vært mindre påaktet - dette til tross for at epilepsirelaterte psykoser har vært kjent blant leger i mange hundre år $(6,7)$.

De distinkte undergruppene postiktal psykose, interiktal psykose og alternativ psykose ble beskrevet $\mathrm{i}$ annen halvdel av 1900tallet (8-10). At epileptiske anfall både kan utløse og bedre en psykose, har skapt spekulasjoner om at det ved begge tilstandene eksisterer en ubalanse mellom eksitatoriske og inhibitoriske cellenettverk (11). Selv om de patofysiologiske mekanismene bak epilepsirelaterte psykoser ikke er fullt ut klarlagt, er det holdepunkter for å tro at det hos mange foreligger dysfunksjonelle limbiske cellenettverk (12).

I en studie fra Taiwan fant man høyere forekomst av epilepsi hos personer med schizofreni enn hos personer uten schizofreni (5,9 ganger større risiko), og omvendt at personer med epilepsi har høyere risiko for å få schizofreni enn personer uten epilepsi (7,7 ganger større risiko) (5). Dette peker muligens mot felles patofysiologiske mekanismer.
En finsk undersøkelse viste at personer med epilepsi hadde 8,5 ganger så høy risiko for å utvikle schizofreni som andre (13). Det å ha en forelder med epilepsi doblet barnets risiko for å få en psykose. Omvendt hadde barn av en forelder med psykose 1,6 ganger så høy risiko for å få epilepsi som andre. Kanskje er det en felles genetisk vulnerabilitet?

At enkelte antiepileptika brukes for å forsterke effekten av antipsykotiske legemidler, understreker ytterligere slektskapet mellom de to tilstandene (14).

I enkelte tilfeller kan trolig psykose hos personer med epilepsi opptre tilfeldig, dvs. uavhengig av epilepsien.

\section{Kunnskapsgrunnlag}

Grunnlaget for denne oversikten er skjønnsmessig valgt ut fra 3603 engelskspråklige metaanalyser, original- og oversiktsartikler funnet i PubMed under søkeordene epilepsy and psychosis, epilepsy and interictal psychosis, epilepsy and postictal psychosis, alternative psychosis and forced normalisation, antiepileptic drugs and psychosis, ECT and mechanism, epilepsy-related psychosis og treatment and epilepsy and psychosis før november 2012 - samt egne kliniske og forskningsmessige erfaringer med epilepsipasienter ved Avdeling for kompleks epilepsi - SSE og ved Røysumtunet habiliteringssenter og hyppig kontakt med nevrologer og psykiatere fra hele landet.

\section{Epidemiologi}

Affektive lidelser, som angst og depresjon, er den hyppigste psykiatriske komorbiditet

\section{Oliver Henning}

oliver.henning@ous-hf.no

Karl 0. Nakken

Avdeling for kompleks epilepsi

Klinikk for kirurgi og nevrofag

Oslo universitetssykehus

Se også kunnskapsprøve på www.tidsskriftet.no/quiz

\section{HOVEDBUDSKAP}

Psykoser ses hos 2-3\% av epilepsipasientene, og de med temporolimbisk epilepsi er særlig utsatt

Det finnes fem psykoseformer: iktale, postiktale, interiktale, alternative og medikamentutløste

Å bedre anfallskontrollen anses som viktigst ved iktale og postiktale psykoser

Ved interiktale og noen tilfeller av postiktale psykoser kan tilleggsbehandling med antipsykotika være indisert 

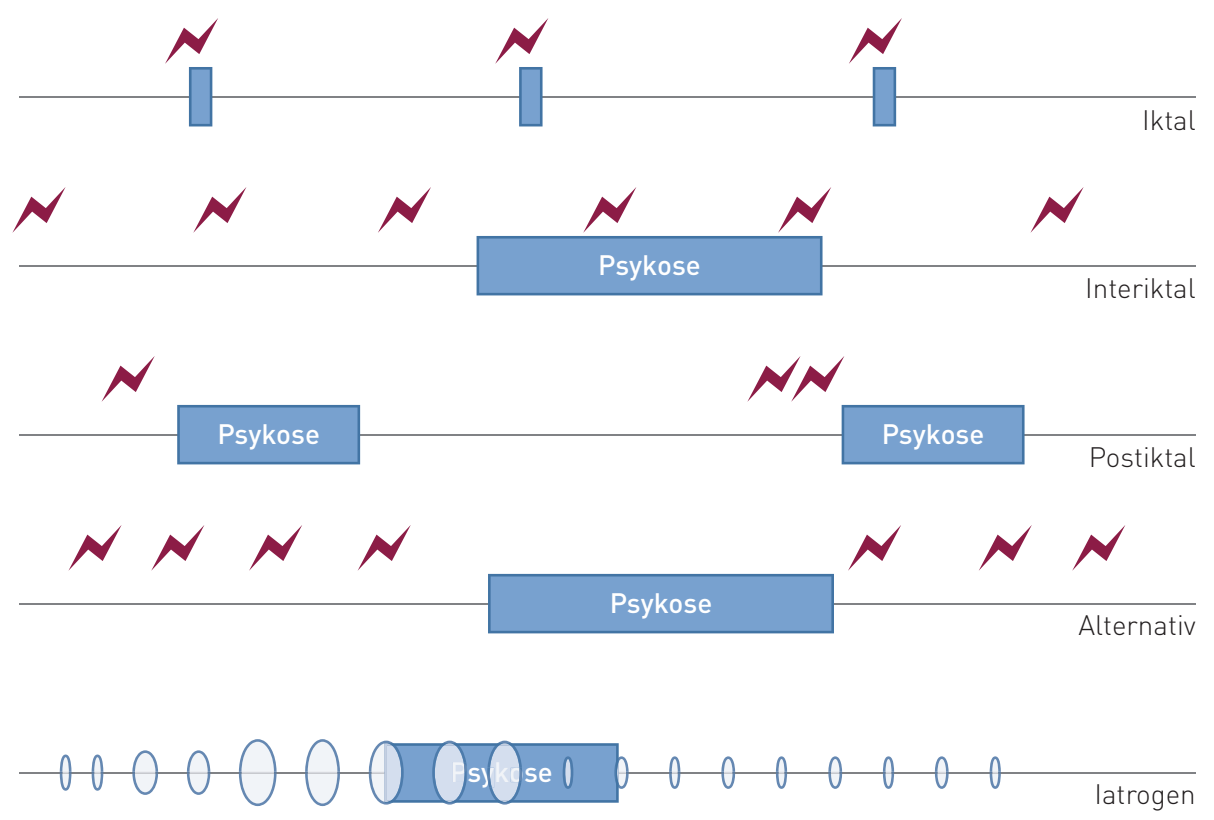

\section{Anfall 0 Antiepileptisk behandling}

Figur 1 Forskjellige epilepsirelaterte psykoser og deres relasjon til anfall og behandling

hos personer med epilepsi (2). Men også forekomsten av psykoser er høyere i epilepsipopulasjonen enn $\mathrm{i}$ den generelle befolkningen $(5,13)$. Gode epidemiologiske undersøkelser er imidlertid mangelvare. Mens psykoseforekomsten i befolkningen ligger på rundt $0,4 \%$ (15), er den $i$ epilepsipopulasjonen estimert til å være $2-3 \%$ (16, 17) og hele $4-9 \%$ blant hospitaliserte epilepsipasienter (18).

\section{Klassifisering}

I de mest brukte diagnoseverktøy (ICD og DSM) finnes det ingen undergrupper av psykiatriske diagnoser ved epilepsi. Fordi pasienter med epilepsi som oftest har psykiatriske symptomer med epilepsispesifikk fenomenologi, har en arbeidsgruppe nedsatt av International League Against Epilepsy foreslått en egen klassifisering av epilepsirelaterte psykiatriske symptomer (19).

Symptomene klassifiseres ut fra deres tidsmessige relasjon til anfall (= ictus) og er enkel å anvende for klinikere. Man skiller mellom iktale, postiktale, interiktale og alternative psykoser. I tillegg kommer psykoser utløst av antiepileptikabruk (fig 1).

\section{Iktale psykoser}

Under et fokalt epileptisk anfall, med eller uten bevissthetsforstyrrelse, kan det opptre psykotiske symptomer som uttrykk for pågående epileptisk aktivitet $i$ deler av hjernen, særlig i limbiske cellenettverk $(20,21)$. Som oftest varer anfallene i under 2-3 minutter, men ved ikke-konvulsiv status epilepticus kan de vare i flere timer, enkelte ganger flere dager.

Symptomene kan variere. Ofte opptrer illusjoner, visuelle og akustiske hallusinasjoner, vrangforestillinger (som ofte kan ha et religiøst innhold), paranoia og tankeforstyrrelser. Pasienten fremstår gjerne som forvirret og er ikke kontaktbar. Slike forvirringstilstander, spesielt ikke-konvulsiv status epilepticus, blir ofte mistolket (22), særlig hvis iktal skalp-EEG ikke viser epileptiform aktivitet. Ved hjelp av EEG fra intracerebrale dybdeelektroder er det vist at illusjoner, hallusinasjoner og vrangforestillinger kan være epileptisk betinget til tross for manglende funn i skalp-EEG $(20,21)$. Det kan føre til at iktale psykoser blir underdiagnostisert.

Nylig er det beskrevet to pasienter som under prekirurgisk langtids-EEG-registrering fikk hallusinasjoner og vrangforstillinger etter en anfallsserie (23). Symptomene var assosiert med iktal epileptisk aktivitet fra innlagte dybdeelektroder. Trolig ville denne iktale aktiviteten ikke vært fanget opp av skalp-EEG-elektroder.

Å stille korrekt diagnose i en slik situasjon kan være vanskelig, men psykotiske symptomer med brå start og slutt hos en pasient med kjent epilepsi burde vekke mistanke.

\section{Postiktale psykoser}

Hyppigst av epilepsirelaterte psykoser er de postiktale. Blant pasienter med terapiresistent epilepsi som er under utredning for epilepsikirurgi, er det funnet en prevalens på
$7,8 \%$ (24). Ved et epilepsisenter fant man en forekomst av postiktale psykoser på rundt $2 \%(25)$.

Til tross for at Jackson allerede i 1875 beskrev opptreden av «temporary mental disorders after epileptic paroxysms» (6), var det først i 1988 at man definerte diagnosekriteriene som fortsatt brukes (ramme 1) (10).

Slike psykoser opptrer som regel hos pasienter med fokale epilepsier som har hatt en serie med fokale anfall og/eller sekundærgeneraliserte krampeanfall. Det typiske er et fritt intervall på 1-3 døgn (maksimalt en uke) mellom anfall og debut av psykosen. De psykotiske symptomene varer sjelden $\mathrm{i}$ mer enn 2-7 døgn, maksimalt 2-3 måneder. Vanligvis opptrer postiktale psykoser mer enn ti år etter epilepsidebuten (25). Hvis psykiatriske symptomer oppstår uten latens etter et anfall eller en anfallsserie, burde man heller mistenke vedvarende anfallsaktivitet, som ved ikke-konvulsiv status, eller en postiktal forvirringstilstand.

Symptomtype og -styrke varierer. Som regel dominerer affektive symptomer, og i en studie ble det funnet depresjon alternerende med hypomani hos 70-90\% (24). Ellers ses paranoide ideer om forfølgelse, akustiske og visuelle hallusinasjoner og religiøse vrangforestillinger. I en studie var forekomsten av målrettet aggresjon og suicidforsøk henholdsvis $22,8 \%$ og $7 \%$ (26).

Det finnes få longitudinelle studier, men hos mange vedvarer tendensen til å få psykoser etter anfall (27). Psykosene opptrer da gjerne på en stereotyp måte. Opptil $25 \%$ utvikler etter hvert en kronisk interiktal psykose (27).

\section{Interiktale psykoser}

Interiktale psykoser opptrer uavhengig av anfall og er sjeldnere, men mer langvarige enn iktale og postiktale psykoser (tab 1) (28). Interiktale psykoser likner «ordinære» schizofrenier, men med den forskjell at pasientene stort sett har et upåvirket stemningsleie. Mange har religiøst pregede vrangforestillinger (9), i mindre grad er det negative symptomer og tankeforstyrrelser $(12,21,7)$.

Det er hevdet at prognosen for pasienter med interiktale psykoser er bedre enn for pasienter med «ordinære» schizofrenier, men det finnes få langtidsstudier (28).

Personer med epilepsi kan også utvikle psykoser helt uavhengig av epilepsien.

\section{Alternative psykoser}

På begynnelsen av 1900-tallet lanserte man en hypotese om at det var en antagonisme mellom epileptiske anfall og psykoser. Ved å påføre pasientene krampeanfall mente man å kunne behandle schizofreni og alvorlig depresjon, noe som fortsatt er det teoretiske grunnlaget for dagens elektrokonvulsive behandling (ECT-behandling) (29). I 1953 beskrev Landolt flere pasienter som utviklet psykiatriske symptomer når deres epilep- 
tiske anfall kom under kontroll og EEGaktiviteten ble normalisert. Han kalte fenomenet «forced normalisation» (8).

Mens Landolt hadde lagt vekt på at EEG ble normalisert, innførte Tellenbach i 1965 begrepet «alternativ psykose» om pasienter som ble psykotiske når anfallene forsvant og der psykosen forsvant når anfallene kom tilbake (30). Insomni og angst var typiske prodromalsymptomer. Mens man ved «forced normalisation» la særlig vekt på EEGforstyrrelsene, var de kliniske symptomene viktigst for å stille diagnosen ved alternativ psykose.

Begrepene har vært omdiskutert. I de senere år har flere understreket at EEG-aktiviteten ikke må normaliseres fullstendig og at det er tilstrekkelig at den epileptiforme aktiviteten avtar (31). Dessuten kan også andre psykiatriske symptomer (f.eks. depresjon, suicidalitet) komme i kjølvannet av oppnådd anfallskontroll, ikke bare psykoser (32). Symptomene kan oppstå uavhengig av om anfallskontrollen er oppnådd ved hjelp av antiepileptika, kirurgi eller vagusnervestimulator (28).

Klinisk kan det være vanskelig å skille alternative psykoser fra bivirkninger av antiepileptika (33). Alternativ psykose er imidlertid ikke knyttet til enkeltmedikamenter. Det betyr at pasienter som tidligere har hatt en alternativ psykose, på ny kan bli psykotiske hvis de får anfallskontroll med en annen type behandling.

Alternative psykoser er en sjelden tilstand. I en studie var forekomsten i en epilepsipopulasjon på $0,5 \%$ (34).

\section{Psykoser utløst}

\section{av antiepileptikabruk}

Psykiatriske symptomer, inkludert psykose, kan opptre som bivirkninger av antiepileptika. Den nøyaktige forekomsten av slike bivirkninger er ikke kjent, men det har vært anslått at $15-40 \%$ av de psykiske symptomene hos epilepsipasienter er forårsaket av behandlingen $(35,36)$.

Av eldre antiepileptika har særlig fenytoin og etosuksimid vært assosiert med psykoser. Av de nye er spesielt vigabatrin, zonisamid, felbamat, topiramat og levetiracetam rappor- tert å kunne gi opphav til psykoser, særlig hos pasienter med en psykiatrisk forhistorie (37). I en studie med ca. 1400 polikliniske pasienter som startet med et nytt antiepileptikum, oftest som ledd i kombinasjonsterapi, var tiagabin $(15,8 \%)$, levetiracetam $(15,7 \%)$, zonisamid $(9,9 \%)$ og topiramat $(6,3 \%)$ de medikamentene som hyppigst var assosiert med psykiske bivirkninger (psykoser, depressive symptomer, irritabilitet m.m.) (38).

Ved nyoppstått psykose hos epilepsipasienter må man alltid vurdere om den kan være fremkalt av behandlingen.

\section{Mulige mekanismer}

Epilepsirelaterte psykoser ses særlig hos pasienter med mangeårig og terapiresistent mesiotemporal epilepsi (28). Hos noen pasienter er det en klar kobling mellom psykosen og anfallene, tidsmessig eller antagonistisk. Omfattende nevrofysiologiske og nevroradiologiske undersøkelser av slike pasienter har vist noe sprikende resultater, men majoriteten har funksjonelle og/eller strukturelle avvik i temporolimbiske strukturer (28). Det er blitt spekulert om endre dopaminerg aktivitet kan være et bindeledd, og det er påvist reduserte striatale dopamin D2-reseptorer hos pasienter med epilepsirelaterte psykoser (39)

Også «kindling», der gjentatte stimuleringer fører til en gradvis lavere anfallsterskel - med ikke bare økte anfall, men også atferdsforandringer - har vært diskutert som en mulig mekanisme (12). En ubekreftet hypotese går ut på at slike psykoser forårsakes av en kompensatorisk økt inhibisjon i limbiske nevronale nettverk (11) som en reaksjon på den økte eksitasjon som ses ved epileptisk aktivitet (40). Den økte inhibisjonen vil etter hvert avta. Men ved spesielt langvarige, kraftige eller hyppige anfall kan det oppstå en overkompensasjon med langvarig økt inhibisjon som kan gi opphav til en psykopatologisk tilstand.

Mens denne hypotesen muligens kan forklare postiktale psykoser, er mekanismene bak alternative psykoser enda mer usikker. I motsetning til psykiske bivirkninger av antiepileptika som ikke nødvendigvis er koblet til anfallsbedring, er alternative psykoser med

\section{RAMME 1}

\section{Diagnosekriterier}

for postiktale psykoser (10)

Etter anfall/opptreden av forvirring eller psykose i løpet av første uke etter tilsynelatende normal postiktal mental funksjon

Varighet 1 dag-3 måneder

Mental status karakterisert av

Redusert bevissthet, desorientering

eller delir

Vrangforestillinger eller hallusinasjon med bevart bevissthet

En kombinasjon av ovenstående

Ingen andre faktorer som kan forklare den unormale mentale tilstanden - som for

eksempel:

Antiepileptikatoksisitet

Tidligere interiktal psykose

Status epilepticus

Forutgående hodetraume eller alkohol-/ narkotikaintoksikasjon.

psykiske symptomer som følger i kjølvannet av anfallsfrihet etter forskjellige behandlingsmodaliteter nokså sjeldent. Mens postiktale psykoser utløses av anfall, forsvinner den alternative psykosen når anfallene kommer tilbake. Dette likner på effekten av elektrokonvulsiv behandling. Heller ikke ved slik behandling er mekanismene bak den psykostabiliserende effekten klarlagt. Man har spekulert på om epileptiske anfall gir økt frisetting av psykoaktive nevrotransmittere eller aktivering av cellenettverk i hippocampus, hypofyse-hypothalamus eller i prefrontal cortex (29). Landolt selv forklarte tilstanden som uttrykk for en overkompensert inhibitorisk prosess (8).

Kanskje foreligger hos disse pasientene nevronale nettverk hvor det er oppstått en ubalanse av psykoaktive nevrotransmittere som ville gitt psykiske problemer om ikke gjentatte epileptiske anfall (ev. elektrokonvulsiv behandling) hadde ført til en stabilisering. Med anfallskontroll forsvinner denne

Tabell 1 Noen kliniske karakteristika hos pasienter med epilepsirelaterte psykoser. Etter Schmitz \& Trimble (28)

\begin{tabular}{llll} 
& Iktal & Interiktal & Postiktal \\
Bevissthet & Redusert & Bevart & Bevart eller redusert \\
Typiske trekk & Varierende symptomer & $\begin{array}{l}\text { Schizofreniliknende } \\
\text { psykopatologi }\end{array}$ & Fritt intervall, 2-3 dager \\
Varighet & $\begin{array}{l}\text { Sekunder til minutter. Ved ikke-kon- } \\
\text { vulsiv status epilepticus ev. dager }\end{array}$ & Måneder & Få dager, maks 3 måneder \\
EEG & Pågående iktal epileptiform aktivitet & Uendret & Unitial insomni, anfalls- \\
Behandling & Antiepileptika & Antipsykotika & Okt epileptiform aktivitet \\
& & & $\begin{array}{l}\text { Bedre anfalls-kontrollen, ev. ben- } \\
\text { zodiazepiner eller antipsykotika }\end{array}$ \\
\hline
\end{tabular}


stabiliseringen, og det oppstår psykiske symptomer.

\section{Behandling}

Ved alle epilepsirelaterte psykoser bør man primært søke å bedre anfallskontrollen. Et unntak er alternative psykoser, der vi anbefaler forsiktig dosenedtrapping av det aktuelle antiepileptikum $(12,41)$ og samtidig iverksetting av tiltak for å bedre søvnen. I denne spesielle situasjonen tilstreber man en økning av den epileptiforme aktiviteten og/eller anfall for å bedre psykosen, som ofte reduserer livskvaliteten i større grad enn epileptiske anfall.

Når det gjelder antipsykotisk behandling, finnes det noen anbefalinger $(21,41)$ som imidlertid ikke er basert på kontrollerte studier, men hovedsakelig på kliniske erfaringer. I en Cochrane-oversikt om behandling av epilepsirelaterte psykoser fra 2008 (42) fant man bare én randomisert, kontrollert studie. I denne studien, som omfattet få pasienter, var det bedre effekt av olanzapin enn av haloperidol (43).

Selv om det er beskrevet kasuistikker der epilepsirelaterte psykoser er bedret som følge av kun antiepileptisk behandling (44), synes det å være bred enighet om at man ved interiktale og enkelte postiktale psykoser bør forsøke en kombinasjon av antiepileptika og antipsykotika $(12,23)$.

Spørsmålet om hvilket antipsykotikum man bør velge, er vanskelig å besvare på grunn av mangel på randomiserte studier. Men både dyreforsøk og kliniske erfaringer har vist at antipsykotika kan senke anfallsterskelen for epilepsipasienter. Det gjelder spesielt klozapin $(41,45)$. En rapport fra WHO om bivirkninger ved bruk av psykotrope medikamenter i perioden1968-2006 viste at klozapin, klorprotiksen og quetiapin var de nevroleptika som hyppigst var assosiert med epileptiske anfall (46). Fordi det som meldes inn til slike registre ofte er nokså tilfeldig, må disse resultatene tolkes med forsiktighet. En metaanalyse av fase 2og fase 3-studier av psykotrope medikamenter registrert i USA i perioden 1985-2004 viste at klozapin $(3,5 \%)$ og olanzapin $(0,9 \%)$ var assosiert med en signifikant økt anfallsrisiko (47). Risperidon hadde lavest risiko for å utløse anfall $(0,3 \%)$. Fordi dette er studier med psykiatriske pasienter uten epilepsi, lar de seg ikke uten videre overføre til epilepsipopulasjonen.

Risperidon er i to studier blitt brukt hos barn og ungdommer med epilepsi og atferdsproblemer $(48,49)$. Begge studiene viste at ca. $70 \%$ fikk bedret atferd og ingen eller kun en liten (4\%) økning i anfallsfrekvens. Det stemmer godt med vår kliniske erfaring.

Iktale psykoser er som oftest av så kort varighet at akutt antipsykotisk behandling er uaktuelt. Her gjelder det å oppnå best mulig anfallskontroll.

Postiktale psykoser er ofte også kort- varige og forbigående, og optimal anfallskontroll er den beste profylaksen. Dog kan enkelte pasienter ha svært uttalte symptomer og være til fare for både seg selv og andre. I slike tilfeller kan akuttbehandling være nødvendig. Benzodiazepiner foretrekkes av mange, også for å forebygge flere anfall. Hos pasienter som tidligere har hatt postiktale psykoser, kan man etter en anfallsserie gi benzodiazepiner profylaktisk (27). I enkelte tilfeller med hyppige postiktale psykoser kan man vurdere å gi et antipsykotikum som profylakse (24).

Ved Avdeling for kompleks epilepsi ved Oslo universitetssykehus har vi god erfaring med bruk av risperidon og aripiprazol hos epilepsipasienter med behov for et antipsykotikum. Spesielt vil vi fraråde bruk av klozapin. Den antipsykotiske effekten ved bruk av risperidon og aripiprazol er omtrent den samme som hos psykiatriske pasienter uten epilepsi, mener vi, ut fra klinisk erfaring.

\section{Konklusjon}

Psykoser hos personer med epilepsi er relativt sjeldent, men de kan ha et dramatisk forløp. Å kjenne til de forskjellige psykoseformene og deres behandling er derfor viktig for alle som behandler denne pasientgruppen, både innenfor nevrologi og psykiatri.

Epilepsirelaterte psykoser er en illustrasjon på at dysfunksjonelle nevronale nettverk kan gi opphav til både nevrologiske og psykiatriske symptomer. Fremtidige studier av slike pasienter, med bruk av så vel strukturelle som funksjonelle diagnostiske metoder, vil forhåpentligvis gi oss bedre innsikt 1 mekanismene bak så vel epileptiske som psykiatriske symptomer.

\section{Oliver Henning (f. 1965)}

er spesialist i nevrologi og psykiatri, med spesialkompetanse i epileptologi. Han er overlege. Forfatter har fylt ut ICMJE-skjemaet og oppgir ingen interessekonflikter.

\section{Karl O. Nakken (f. 1945)}

er spesialist i nevrologi, med spesialkompetanse i epileptologi. Han er medisinsk sjef. Forfatter har fylt ut ICMJE-skjemaet og oppgir følgende interessekonflikter: Han har mottatt reisestøtte og foredragshonorar fra GSK, Esai og UCB

\section{Litteratur}

1. Reynolds EH, Kinnier Wilson JV. Psychoses of epilepsy in Babylon: the oldest account of the disorder. Epilepsia 2008; 49: 1488-90.

2. Tellez-Zenteno JF, Patten SB, Jetté N et al. Psychiatric comorbidity in epilepsy: a populationbased analysis. Epilepsia 2007; 48: 2336-44.

3. Rai D, Kerr MP, McManus S et al. Epilepsy and psychiatric comorbidity: a nationally representative population-based study. Epilepsia 2012; 53 : 1095-103.

4. Forsgren L, Nyström L. An incident case-referent study of epileptic seizures in adults. Epilepsy Res 1990; 6: 66-81

5. Chang YT, Chen PC, Tsai IJ et al. Bidirectional relation between schizophrenia and epilepsy: a population-based retrospective cohort study. Epilepsia 2011; 52: 2036-42.

6. Jackson JH. On temporary mental disorders after epileptic paroxysms. West Riding Pauper Lunatic Asylum Med Rep 1875; 5: 105-29.

7. Köhler GK. Epileptische Psychosen: Klassifikationsversuche und EEG-Verlaufsbeobachtungen. Fortschr Neurol Psychiatr 1975; 43: 99-153.

8. Landolt H. Some clinical EEG correlations in epileptic psychoses (twilight states). Electroencephalogr Clin Neurophysiol 1953; 5: 121.

9. Slater E, Beard AW, Glithero E. The schizophrenialike psychoses of epilepsy. Br J Psychiatry 1963; 109: $95-150$

10. Logsdail SJ, Toone BK. Post-ictal psychoses. A clinical and phenomenological description. Br J Psychiatry 1988; 152: 246-52

11. Sachdev PS. Alternating and postictal psychoses: review and a unifying hypothesis. Schizophr Bull 2007; 33: 1029-37.

12. Brewerton TD. The phenomenology of psychosis associated with complex partial seizure disorder. Ann Clin Psychiatry 1997: 9: 31-51.

13. Clarke MC, Tanskanen A, Huttunen MO et al. Evidence for shared susceptibility to epilepsy and psychosis: a population-based family study. Biol Psychiatry 2012; 71: 836-9.

14. Hasan A, Falkai P. Wobrock T et al. World Federation of Societies of Biological Psychiatry (WFSBP) Guide lines for Biological Treatment of Schizophrenia, part 1: update 2012 on the acute treatment of schizophrenia and the management of treatment resistance. World J Biol Psychiatry 2012; 13: 318-78

15. Jenkins R, Bebbington P, Brugha TS et al. British psychiatric morbidity survey. Br J Psychiatry 1998 173: 4-7.

16. Bredkjaer SR, Mortensen PB, Parnas J. Epilepsy and non-organic non-affective psychosis. Nationa epidemiologic study. Br J Psychiatry 1998; 172 $235-8$.

17. Qin $P, X u H$, Laursen TM et al. Risk for schizophrenia and schizophrenia-like psychosis among patients with epilepsy: population based cohort study. BMJ 2005; 331: 23.

18. Matsuura M, Adachi N, Muramatsu R et al. Intellectual disability and psychotic disorders of adult epilepsy. Epilepsia 2005; 46 (suppl 1): 11-4.

19. Krishnamoorthy ES, Trimble MR, Blumer D The classification of neuropsychiatric disorders in epilepsy: a proposal by the ILAE Commission on Psychobiology of Epilepsy. Epilepsy Behav 2007 10: $349-53$

20. Elliott B, Joyce E, Shorvon S. Delusions, illusions and hallucinations in epilepsy: 1. Elementary phenomena. Epilepsy Res 2009. 85: 162-71.

21. Elliott B, Joyce E, Shorvon S. Delusions, illusions and hallucinations in epilepsy: 2. Complex phenomena and psychosis. Epilepsy Res 2009; 85 : $72-86$

22. Haver B. Fra syk lege til vanskelig pasient. Tidsskr Nor Laegeforen 2004; 124: 373-5.

23. Kuba R, Brázdil M, Rektor I. Postictal psychosis and its electrophysiological correlates in invasive EEG: a case report study and literature review. Epilepsy Behav 2012; 23: 426-30.

24. Kanner AM, Stagno S, Kotagal $P$ et al. Postictal psychiatric events during prolonged video-electroencephalographic monitoring studies. Arch Neurol 1996: 53: 258-63.

25. Kanemoto K. Postictal psychoses, revisited. I: Trimble M, Schmitz B, red. The neuropsychiatry of epilepsy. Cambridge: Cambridge University Press, 2002: 117-31.

26. Kanemoto K, Tadokoro Y, Oshima T. Violence and postictal psychosis: a comparison of postictal psychosis, interictal psychosis, and postictal confusion. Epilepsy Behav 2010; 19: 162-6.

27. Trimble M, Kanner A, Schmitz B. Postictal psychosis. Epilepsy Behav 2010; 19: 159-61.

28. Schmitz B, Trimble M. Psychoses and forced normalization. I: Schachter SC, Holmes GL, Kasteleijn-Nolst Trenite DGA, red. Behavioral aspects of epilepsy. New York, NY: Demos Medical Publishing, 2008: 235-43.

29. Bolwig TG. How does electroconvulsive therapy work? Theories on its mechanism. Can J Psychiatry 2011; 56: 13-8. 
30. Tellenbach H. Epilepsie als Anfallsleiden und als Psychose. Über alternative Psychosen paranoider Prägung bei «forcierter normalisierung» (Landolt) des Elektroencephalogramms Epileptischer. Nervenarzt 1965; 36: 190-202

31. Krishnamoorthy ES, Trimble MR. Forced normalization: clinical and therapeutic relevance. Epilepsia 1999; 40 (suppl 10): S57-64.

32. Wolf P. Acute behavioral symptomatology at disappearance of epileptiform EEG abnormality. Paradoxical or «forced» normalization. Adv Neurol 1991; 55: 127-42.

33. Weber P, Dill P, Datta AN. Vigabatrin-induced forced normalization and psychosis-prolongated termination of behavioral symptoms but persistent antiepileptic effect after withdrawal. Epilepsy Behav 2012; 24: 138-40.

34. Schmitz B, Wolf P. Psychosis in epilepsy: frequency and risk factors. J Epilepsy 1995; 8: 295-305.

35. Schmitz EB, Robertson MM, Trimble MR. Depression and schizophrenia in epilepsy: social and biological risk factors. Epilepsy Res 1999; 35: 59-68.

36. Matsuura M. Epileptic psychoses and anticonvulsant drug treatment. J Neurol Neurosurg Psychiatry 1999; 67: 231-3.

37. Nadkarni S, Devinsky O. Psychotropic effects of antiepileptic drugs. Epilepsy Curr 2005; 5: 176-81.
38. Weintraub D Buchsbaum R, Resor SR Jr et al. Psychiatric and behavioral side effects of the newer antiepileptic drugs in adults with epilepsy. Epilepsy Behav 2007; 10: 105-10.

39. Ring HA, Trimble MR, Costa DC et al. Striatal dopamine receptor binding in epileptic psychoses. Biol Psychiatry 1994; 35: 375-80.

40. Tebartz van Elst L, Krishnamoorthy ES, SchulzeBonhage $A$ et al. Local area network inhibition: a model of a potentially important paraepileptic pathomechanism in neuropsychiatric disorders. Epilepsy Behav 2011; 22: 231-9.

41. Kerr MP, Mensah S, Besag F et al. International consensus clinical practice statements for the treatment of neuropsychiatric conditions associated with epilepsy. Epilepsia 2011; 52: 2133-8.

42. Faroog S, Sherin A. Interventions for psychotic symptoms concomitant with epilepsy. Cochrane Database Syst Rev 2008; 4: CD006118. doi: 10.1002/14651858.CD006118.pub2

43. Thomas A, Boungarzone MP, Luciano AL et al. Safe administration of olanzapine in psychotic epilepsy patients. Epilepsia 2002; 43 (suppl 8): 180.

44. Needham E, Hamelijnck J. Temporal lobe epilepsy masquerading as psychosis - a case report and literature review. Neurocase 2012; 18: 400-4.
45. Devinsky O, Honigfeld G. Patin J. Clozapine-related seizures. Neurology 1991; 41: 369-71.

46. Kumlien E, Lundberg PO. Seizure risk associated with neuroactive drugs: data from the WHO adverse drug reactions database. Seizure 2010 19: 69-73

47. Alper K, Schwartz KA, Kolts RL et al. Seizure incidence in psychopharmacological clinical trials: an analysis of Food and Drug Administration (FDA) summary basis of approval reports. Biol Psychiatry 2007; 62: 345-54.

48. Gonzalez-Heydrich J, Pandina GJ, Fleisher CA et al. No seizure exacerbation from risperidone in youth with comorbid epilepsy and psychiatric disorders: a case series. J Child Adolesc Psychopharmacol 2004; 14: 295-310.

49. Holzhausen SP, Guerreiro MM, Baccin CE et al. Use of risperidone in children with epilepsy. Epilepsy Behav 2007; 10: 412-6.

Mottatt 24.10. 2012, første revisjon innsendt 10.3. 2013, godkjent 23.4. 2013. Medisinsk redaktør Trine B. Haugen. 